Rafał Tyszkiewicz ${ }^{1}$, Monika Tyszkiewicz ${ }^{2}$

\title{
KULTURA ORGANIZACYJNA W POGLĄDZIE ZARZĄDZANIA PRZEDSIECBIORSTWEM PRODUKCYJNYM
}

\begin{abstract}
Streszczenie: Celem artykułu jest identyfikacja znaczenia kultury organizacyjnej w przedsiębiorstwie produkcyjnym. Badania przeprowadzono korzystając $z$ danych literaturowych oraz wykorzystano metodę sondażu diagnostycznego, a jako narzędzie badawcze wykorzystano kwestionariusz ankiety, który przeprowadzono z 53 pracownikami przedsiębiorstwa produkcyjnego.
\end{abstract}

Słowa kluczowe: kultura organizacyjna, menedżer, normy, wartości

\section{Wprowadzenie}

Kultura organizacyjna to jedna $\mathrm{z}$ podstawowych więzi społecznych, dzięki której pracownik może nawiązywać nowe znajomości, czuć się dobrze w miejscu pracy. Za pomocą kultury organizacyjnej kształtują się trwałe wartości, normy oraz zachowania. Kultura organizacyjna to sposób, w jaki członkowie jednego przedsiębiorstwa odnoszą się do swojej pracy, do siebie samych oraz do świata zewnętrznego odróżniając się tym od członków pozostałych organizacji. Kultura organizacyjna zwiększa szanse na osiągnięcie sukcesu w przedsiębiorstwie oraz pomaga zbudować przewagę nad konkurencją. Celem artykułu jest identyfikacja znaczenia kultury organizacyjnej w przedsiębiorstwie produkcyjnym zlokalizowanym na terenie województwa dolnośląskiego. Badania przeprowadzono korzystając z danych literaturowych oraz wykorzystano metodę sondażu diagnostycznego, a jako narzędzie badawcze wykorzystano kwestionariusz ankiety, który przeprowadzono z 53 pracownikami przedsiębiorstwa produkcyjnego. Ta część badań została zaprezentowana $\mathrm{w}$ formie analizy przypadku. Przeprowadzone badanie miało charakter pilotażowy i stanowi zaledwie początek badań empirycznych nad specyfiką kulturową organizacji produkcyjnych. Ze względu na brak zgody na udostępnienie nazwy przedsiębiorstwa na podstawie, której zawarte są informacje w analizie przypadku artykułu, zawarto odniesienie do nazwy ,,przedsiębiorstwo produkcyjne”.

\footnotetext{
${ }^{1}$ Dr, Wyższa Szkoła Bankowa we Wrocławiu, e-mail: rafal.tyszkiewicz@wsb.wroclaw.pl, ORCID ID: 0000-0003-1525-0697

${ }^{2}$ Mgr, Wyższa Szkoła Bankowa we Wrocławiu, e-mail: monika.tyszkiewicz@wsb.wroclaw.pl, ORCID ID: 0000-0001-6785-966X
} 


\section{Rola kultury organizacyjnej w przedsiębiorstwie}

W ostatnim dwudziestoleciu wielu autorów podjęło się próby zdefiniowania pojęcia kultura organizacyjna. Najbardziej rozpowszechnioną jest definicja E.H Scheina który zdefiniował ją jako zespół rozsądnych reguł postępowania, odkrytych, ustanowionych i rozwiniętych przez grupę, służących do zmagania się z problemami wewnętrznej integracji i zewnętrznym dostosowaniem, które dzięki wystarczająco dobremu działaniu wytyczają nowym pracownikom sposób myślenia i odczuwania $\mathrm{w}$ aspekcie wspomnianych problemów [1].

Kultura organizacyjna odgrywa ważną rolę w przedsiębiorstwie. Udziela się pracownikom pod różnymi formami. Do przejawów form kultury przedsiębiorstwa należy zaliczyć: symbole, sposób komunikowania się, rytuały, wartości i mity. Symbole pozwalają odczytywać znaczenia, które dostrzega się za pomocą wzroku. Można je przedstawić $\mathrm{w}$ różnych formach. W organizacji obejmują symbolikę architektoniczną, fizyczną i statusu. Pierwsza dotyczy wystroju wnętrz, rozplanowania biura, zewnętrzną architekturę przedsiębiorstwa, organizację parkingów itp. Symbolika fizyczna wskazuje na wygląd i sposób ubierania się pracowników. Natomiast do symboliki statusu zalicza się nagrody, przywileje służbowe. Te symbole coraz bardziej nabierają większego znaczenia w organizacjach. Ważny element w przedsiębiorstwie pełni sposób komunikowania się. Kultura organizacyjna wpływa na procesy komunikacyjne, które występują wewnątrz organizacji. Natomiast procesy wpływają na strukturę kultury organizacyjnej [2].

Komunikacja pełni ważną rolę w działalności menedżera, ponieważ dąży on do osiągania celów, dzięki pracy z ludźmi. Komunikowanie umożliwia wymianę informacji, pozwala zmieniać zachowania podległych pracowników, kształtować ich obraz oraz relacje. Komunikacja jest wspólna pod względem wszystkich funkcji zarządzania w przedsiębiorstwie.

W kulturze organizacji powstaje dużo rytuałów i zwyczajów. Można do nich zaliczyć zatrudnianie nowych pracowników czy ich zachowania np. sposoby witania się oraz udział w ceremoniach społecznych np. spotkania biznesmenów. Rytuały to powtarzane działania, które wzmacniają podstawowe wartości występujące w organizacji. Zaś wartości w przedsiębiorstwie podkreślają to co jest, akceptowalne oraz pożądane w organizacji. Zarządzanie przy użyciu wartości skupia się na czynniku ludzkim, ponieważ przedsiębiorstwa próbują stwarzać grupy aktywnych, oddanych pracowników, lojalnych klientów czy właścicieli, którzy zajmują się wizerunkiem i prestiżem przedsiębiorstwa [3].

Wartości determinują zachowania pracowników oraz przedstawiają wizerunek przedsiębiorstwa. W każdej organizacji wyodrębnione jednoznaczne normy, wartości 
czy postawy uznawane przez pracowników stanowią zwarte systemy, będące częścią strategii zarządzania. Wartości w organizacji tworzą się pod wpływem: otoczenia, konieczności utrzymania prawidłowych relacji zawodowych pośród członków przedsiębiorstwa, czynności kadry zarządzającej bądź założyciela, pojawiania się ważnych incydentów [2]. Mity są opowieściami podkreślającymi to, co jest akceptowane w danej kulturze, wpływają na wartości oraz wierzenia, którymi kieruje się każdy człowiek. Po pierwsze, można je lepiej zapamiętywać np. historie przedsiębiorstwa niż statystyczne cyfry. Także, dzięki opowieściom można utrzymać wartości przedsiębiorstwa przy życiu [4]. Zależności pomiędzy kulturą organizacyjną a kulturą narodową ukazał G. Hofstede. Wyróżnia on takie wymiary kultur jak:

1. Dystans wobec władzy, gdzie występuje akceptacja nierównego podziału władzy. Członkowie organizacji muszą przyjmować polecenia i wskazówki kierowników. W organizacjach w których można dostrzec niski dystans władzy pracownicy są krytyczni, wyrażają swoje wątpliwości.

2. Indywidualizm - kolektywizm, w przedsiębiorstwach w których widać dominację indywidualizmu pracownicy przywiązują duży stopień samodzielności, cenią sobie wyzwania. Natomiast tam, gdzie dostrzega się kolektywizm cenione są odpowiednie warunki pracy, widoczne jest nastawienie na pracę grupową.

3. Męskość - kobiecość, kultura męska oznacza podejmowanie wyzwań, dochodzenie do celów indywidualnych, chęć osiągania wysokich zarobków przez pracowników. Cenione wartości to: rywalizacja, podnoszenie jakości produktów, efektywność i energia działania pracowników. W kulturze kobiecej można dostrzec dążenie ludzi od harmonijnej współpracy, pewność zatrudnienia czy zgodne stosunki. Jest ona przyjazna dla pracowników, ponieważ nawet niekompetentne osoby nie są zwalniane, co jest skutkiem wysokiego poziomu ich lojalności w stosunku do firmy.

4. Unikanie niepewności, stopień zagrożenia, który można odczuwać w związku $\mathrm{z}$ niejasnością działalności kadry zarządzającej. Pojawia się w takich zachowaniach jak: stres w miejscu pracy, chęć przełamania barier w przedsiębiorstwie.

5. Konfucjański dynamizm, stopień w jakim pracodawcy są skłonni do zaakceptowania sytuacji niepewności zmiany. Mały stopień niepewności, czyli brak stresów, bezpieczeństwo, a duży to nietolerancja, pojawiające się konflikty [5].

Kultura organizacyjna zależy w dużym stopniu od rodzaju i wielkości przedsiębiorstwa. W inny sposób zarządza się przedsiębiorstwem produkcyjnym a usługowym, inaczej przedsiębiorstwem małym a dużym. Istotne tu znaczenie odgrywają na kształtowanie kultury organizacyjnej czynniki do których zalicza się: 
1. Cechy organizacji, bardzo duże znaczenie dla kultury organizacyjnej ma historia, wiek oraz wielkość przedsiębiorstwa. Także ogromny wpływ na kulturę ma styl zarządzania. W przedsiębiorstwach, gdzie występuje styl autokratyczny, kultura skupia się na wartościach (lojalności i posłuszeństwu). Preferowany demokratyczny styl zarządzania to większą skłonność do bycia odpowiedzialnym oraz ukierunkowanie na samodzielność pracowników przedsiębiorstwa.

2. Typ organizacji, ważna w kulturze jest zastosowana technologia, forma własności, branża oraz warunki, jakie panują na rynku.

3. Cechy uczestników, indywidualny wkład w kulturę stanowi każdy pracownik zajmujący miejsce w organizacji mający własne normy i wartości oraz poglądy. Ważne znaczenie pod tym względem pełni struktura zatrudnienia dzielona na płeć, a także struktura wiekowa pracowników. W przedsiębiorstwach, gdzie zatrudnione są starsze osoby dominują wartości, do których można zaliczyć spokój, bezpieczeństwo, tradycję. Natomiast młodzi pracownicy posiadają skłonność do ryzyka, są gotowi na zmiany, wnoszą więcej dynamiki [6]. Skłonność przedsiębiorstw do budowania kultury organizacyjnej stwarza konieczność dostosowania jej $\mathrm{w}$ dalszej perspektywie działania przedsiębiorstwa. Dzięki kulturze organizacyjnej, która została zaliczona do czynników umożliwiających osiągnięcie przewagi konkurencyjnej, organizacje odnoszą sukces, ponieważ to ona scala, jednoczy, stabilizuje, sprzyja wspólnemu widzeniu celów lub ułatwia znajdowanie sposobów rozwiązywania problemów. Daje ona mocne osadzenie dla działań strategicznych organizacji [7].

Idea zarządzania przez kulturę stanowi skutek poszukiwań nowych narzędzi zarządzania takich jak np. TQM czy zarządzanie relacjami $\mathrm{z}$ interesariuszami organizacji. Tu należy, podkreślić, iż sukces każdej organizacji zależy od zaangażowania jej pracowników. Aby tak się stało zespół powinien mieć przekonanego w wartości menedżera dążącego do ciągłego procesu kształtowania relacji $\mathrm{z}$ nimi. Celem kultury jest wspieranie procesów zarządzania $\mathrm{W}$ przedsiębiorstwie, ponieważ jej zawodność oraz stabilność wpływa na efektywność w pracy. Także zaakceptowane przez pracowników wzorce umożliwiają samokontrolę oraz wywołują w nich zaangażowanie w pracę.

Reasumując, zbudowanie innowacyjnej kultury organizacyjnej przedsiębiorstwa wymaga posiadania kreatywnej kadry menedżerskiej i pracowniczej. Kompetencje kadry menedżerskiej, związane ze współdziałaniem i współpracą z otoczeniem zewnętrznym organizacji, mają podstawowe znaczenie dla korporacyjnej przedsiębiorczości, zaś rola pracowników wykonawczych, nie powinna być zawężana do przestrzegania zdefiniowanych procedur, norm i standardów, ponieważ to 
kompetencje wszystkich pracowników decydują w dużym stopniu o konkurencyjności przedsiębiorstwa [8].

\section{Studium przypadku}

Autorzy przeprowadzili badania w zakresie identyfikacji kultury organizacyjnej w przedsiębiorstwie produkcyjnym z branży okiennej z województwa dolnośląskiego. Respondentami badań byli pracownicy przedsiębiorstwa (głównie $\mathrm{z}$ linii produkcyjnej) oraz pracownicy biurowi. Łącznie przebadano 53 pracowników. Kultura organizacyjna jako przedmiot badań w „przedsiębiorstwie produkcyjnym” zobrazowana na rysunku 1 jako zbiorcze wyniki badań, opiera się na równości, otwarciu na nowe wpływy oraz zaufaniu.

Pracownicy tego przedsiębiorstwa wyróżniają się otwartością, chęcią współpracy oraz pasją do tego co robią. Przedsiębiorstwo daje im szerokie możliwości znalezienia miejsca na różnym etapie swojego rozwoju zawodowego (ponad $84 \%$ ankietowanych pracowników „zdecydowanie tak” bądź „tak” odpowiedziało na zadane pytanie). Przedsiębiorstwo wspiera rozwój pracowników poprzez indywidualne rozmowy o ich ścieżce kariery, szereg szkoleń i programów rozwojowych, ocenę roczną, a także coaching i mentoring. W przedsiębiorstwie każdy pracownik ma takie same szanse oraz prawa rozwoju. Natomiast talenty są otaczane troską. Gdy taki pracownik pragnie robić coś więcej, chce się rozwijać to ma możliwość np. ustala indywidualną ścieżkę rozwoju ze swoim przełożonym. Nie istnieje podział na pracowników ,lepszych” oraz ,gorszych”.

Istotną powagę wskazują wartości w przedsiębiorstwie. Widoczny entuzjazm i poczucie wspólnoty wskazuje na integrację, co w znacznym stopniu wpływa na sukcesy całej organizacji. Wymaga się szacunku do siebie oraz interesantów zewnętrznych. Istotnie ważne jest to, aby $\mathrm{w}$ przedsiębiorstwie była atmosfera przyjaźni oraz współpracy. W omawianym ,przedsiębiorstwie produkcyjnym” bardzo ważna jest atmosfera pracy. Postawą osiągnięcia wspólnego sukcesu jest zaufanie oraz wzajemna pomoc. $89 \%$ respondentów wskazało, iż przedsiębiorstwo stwarza pracownikom komfort psychiczny i emocjonalny.

„Przedsiębiorstwo produkcyjne” wyróżnia się kulturą zrównoważoną. Ceni otwartość na otoczenie, traktując je jako spektrum możliwości, z których można czerpać szereg wartości. Wspiera oraz ceni sobie pracowników pełnych energii, pomysłów, zdeterminowanych we wspólnym osiąganiu celów organizacji. Wśród badanych panuje przekonanie, iż menedżerowie zasięgają opinii pracowników i biorą ich twórcze pomysły, aż 48\% badanych odpowiedziało się ,zdecydowanie tak” , natomiast $20 \%$,tak". Przestrzeganie zasad etycznych ma szczególne znaczenie dla menedżerów, gdyż przez tworzenie warunków pracy, mają oni zasadniczy wpływ 
zarówno na pracowników oraz kontrahentów przedsiębiorstwa. Kolejnym pytaniem związanym z przejawem formy kultury organizacyjnej przedsiębiorstwa jest uczciwy i etyczny sposób zarządzania przedsiębiorstwem. Ponad 83\% respondentów zadeklarowała uczciwy i etyczny sposób zarządzania przedsiębiorstwem przez menedżerów. Respondenci również zostali poproszeni o zdeklarowanie, czy kierownictwo umiejętnie przydziela im zadania i sprawnie koordynuje ich pracę. $22 \%$ badanych odpowiedziało „zdecydowanie tak”, 25\% „tak”, natomiast 28\% odpowiedziało „czasami”, 17\% stwierdziło, że „nie”.

Kierownictwo kładzie nacisk na rozwój osobisty oraz podejmowanie nowych wyzwań

Kierownictwo ma klarowną wizję celów organizacji $\mathrm{i}$ wie jak ją realizować

Kierownictwo umiejętnie przydziela pracownikom określone zadania i sprawnie.

Kierownictwo na bieżąco informuje pracowników o ważnych zmianach

Kierownictwo zarządza przedsiębiorstw em w sposób uczciwy $i$ etyczny

Przedsiębiorstwo oferuje wyjątkowe św iadczenia pracownicze

Kierownictwo angażuje pracowników w proces podejmowania decyzji

Kierownictwo zasięga opinii pracowników i bierze pod uwagę ich twórcze pomysły

Kierownictwo docenia wysoką jakość pracy pracowników

Pracownikowi przydziela się szeroki zakres odpowiedzialności

Sposób urządzenia przedsiębiorstwa stwarza dobre warunki do pracy

Przedsiębiorstwo stwarza pracownikom komfort psychiczny i emocjonalny

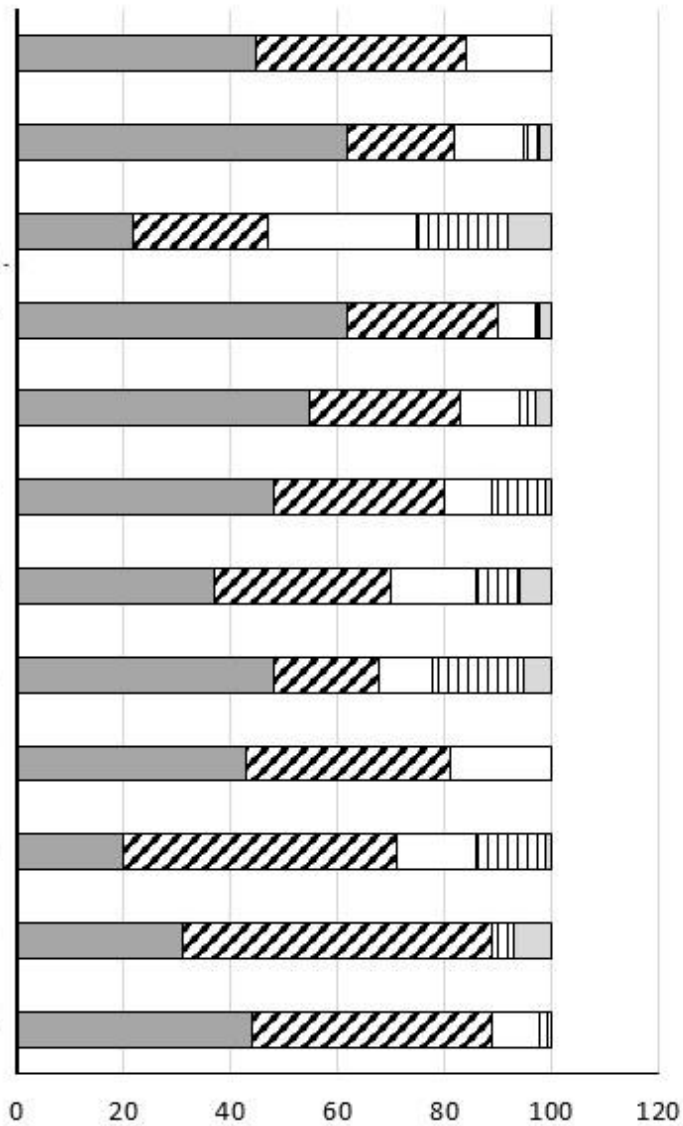

$\square$ zdecydowanie tak $\square$ tak $\square$ czasami $\square$ nie $\square$ zdecydowanie nie

Rys. 1. Wyniki badań dotyczace kultury organizacyjnej w przedsiębiorstwie przemyslowym

Źródto: opracowanie wtasne 
Badani menedżerowie doceniają wysoką jakość pracy pracowników, przez co przydziela się pracownikom szeroki zakres odpowiedzialności. Interesujące wydaje się, że kierownictwo angażuje pracowników w proces podejmowania decyzji $70 \%$ badanych odpowiedziało „zdecydowanie tak” i „tak”. Aby bardziej zmotywować i zrekrutować pracowników do przedsiębiorstwa, badane „przedsiębiorstwo produkcyjne" oferuje wyjątkowe świadczenia pracownicze (sfinansowanie biletu kwartalnego na komunikację miejską, pakiety sportowe i medyczne, dofinansowanie do wycieczki dla pracowników i ich rodzin, pełne sfinansowanie nauki na uczelniach wyższych). $80 \%$ badanych odpowiedziało ,zdecydowanie tak” i „tak” na pytanie czy przedsiębiorstwo oferuje wyjątkowe świadczenia pracownicze. Sposób urządzenia przedsiębiorstwa w dużym stopniu wpływa na wyższą wydajność pracowników.

W „przedsiębiorstwie produkcyjnym” jakość pomieszczeń produkcyjnych, biurowych i gospodarczych czy osobnego miejsca na posiłek stwarza dobre warunki do pracy. Jasne, przestrzenne, klimatyzowane czy dobrze wentylowane miejsca pracy wpływają pozytywnie na stopień realizacji wykonywanych przez nich zadań. Obok wyżej wymienionych standardów atrakcyjne jest położenie przedsiębiorstwa oraz obszerny parking dla samochodów pracowniczych. Przemyślane i rozsądne wprowadzane zmian $\mathrm{w}$ przedsiębiorstwie, a w szczególności bieżąca informacja pracowników na temat zmian wymagająca ich aktywnego uczestnictwa, tworzy dobrą atmosferę współpracy i współdziałania w materii przedsiębiorstwa. Blisko 90\% badanych odpowiedziało ,zdecydowanie tak" i ,tak” na pytanie czy kierownictwo na bieżąco informuje pracowników o ważnych zmianach

W „przedsiębiorstwie produkcyjnym” widoczna jest integracja pracowników. $\mathrm{Na}$ odpowiednią integrację pracowników wpływa dobra komunikacja. Dzięki efektywności pracowników produkcyjnych przedsiębiorstwo zmniejszyło ilość reklamacji. Ważny $w$ tym jest wpływ kadry zarządzającej. Od ich relacji z pracownikami, współpracy, odpowiednim nadzorze utrzymuje się porządek organizacyjny $\mathrm{w}$ przedsiębiorstwie. Kultura organizacyjna w badanym „przedsiębiorstwie produkcyjnym” w bardzo dużym stopniu wpływa na funkcjonowanie oraz indywidualne cechy pracowników. Podsumowując całość przeprowadzonych badań można stwierdzić, że kultura organizacyjna $\mathrm{w}$ badanym przedsiębiorstwie wskazuje na wysoki poziom. Normy, wartości, przekonania oraz zachowania, charakteryzują sposób w jaki grupy lub jednostki pracownicze łączą się w celu wykonywania określonych działań. Kultura organizacyjna wzmacnia działania oraz postawy pracowników w przedsiębiorstwie w badanym przedsiębiorstwie. 


\section{Podsumowanie}

Jest oczywiste, że właściwa kultura organizacyjna ma wpływ na efektywność przedsiębiorstwa, ale powinna brać za postawę to iż, każdy pracownik jest źródłem pozytywnych wartości dla przedsiębiorstwa, dlatego należy mu się szacunek. Menedżerowie powinni analizować zmiany w sposób najbardziej obiektywny, natomiast pracownicy inicjować je. Kultura organizacyjna w obecnym zarządzaniu przedsiębiorstwem odgrywa bardzo dużą rolę. Jest to podstawowy budulec, który pozwala stworzyć prawdziwą siłę oraz jedność przedsiębiorstwa. Kierowanie się konkretnymi normami oraz zasadami służy rozwojowi organizacji. Kulturę można zbudować metodą niewielkich kroków: systematycznym, planowym oraz konsekwentnym działaniem. Warto jest budować kulturę oraz umacniać pożądane postawy za pomocą spójnej komunikacji oraz wskazywanie sukcesów i zagrożeń, które są związane z codziennym działaniem przedsiębiorstwa. Kultura organizacyjna kształtuje się przez cały czas funkcjonowania przedsiębiorstwa. Wpływają na nią sukcesy oraz porażki, jego historia, otoczenie, konkurencja, a także członkowie organizacji. Dzięki silnej kulturze przedsiębiorstwo staje się niepowtarzalne oraz uzyskuje przewagę konkurencyjną.

\section{Bibliografia}

[1] Schein E.H.: Organizational Culture and Leadership. Jossey-Bass Publisher, San Francisco 2004, s.59.

[2] Sułkowski Ł., Sikorski C.: Metody zarządzania kultura organizacyjna, Wydawnictwo Difin, Warszawa 2014, s. 138.

[3] Błaszczyk W.: Metody organizacji $i$ zarzadzania, Ksztaltowanie relacji organizacyjnych. Wydawnictwo Naukowe PWN, Warszawa 2005, s. 234.

[4] Zbiegień-Maciąg L.: Kultura $w$ organizacji. Identyfikacja kultur znanych firm. Wydawnictwo Naukowe PWN, Warszawa 2005, s. 49- 50.

[5] Moczydłowska J.: Zachowania organizacyjne $w$ nowoczesnym przedsiębiorstwie. Śląsk Wydawnictwo Naukowe, Katowice 2006, s. 178- 182.

[6] Wajda A.: Podstawy nauki o zarządzaniu organizacjami. Wydawnictwo Difin, Warszawa 2003, s. 260- 263.

[7] Kuc B.R.: Kultura zarzq̨dzania i jej wptyw na sukces organizacji - wprowadzenie do dyskusji. [w:] Kowalczewski W., Kuc B.R., Dyskusje o zarzadzaniu, EMENTON, Warszawa 2016, s.10.

[8] Onufer J.: Spoleczne aspekty zarzadzania bezpieczeństwem pracy $w$ procesach outsourcingu. Zeszyty naukowe Politechniki Łódzkiej Organizacja i Zarządzanie $\mathrm{Nr}$ 1202, z.61, Łódź 2015, s.189. 


\title{
ORGANIZATIONAL CULTURE IN THE VIEW OF MANAGING A MANUFACTURING COMPANY
}

\begin{abstract}
The process of creating an organizational culture becomes very complicated and complex. Its nature is influenced by internal and external factors. The first can include: valued values, respected by all standards, artifacts, created organizational climate and also the prevailing management style. On the other hand, external factors include the impact of a culture characteristic of the organization's environment and the employees employed in it.

Organizational culture helps to build an advantage over competitors and increases the chances of success in a company on the market.
\end{abstract}

Key words: organizational culture, manager, standards, values.

Data przestania publikacji do Redakcji: 02.05.2019

Data akceptacji publikacji przez Redakcję: 06.06.2019

DOI: $10.30657 / q p i .2019 .10 .04$ 